\title{
INFLUENCE OF THE PASTEURIZATION CONDITIONS ON SUGARCANE JUICE PACKAGED IN GLASS PACKAGING
}

\author{
Raquel Bulegon ${ }^{1}$, Gilmar de Almeida Gomes ${ }^{2}$,Elisandra Rigo ${ }^{3}$ \\ ${ }^{1}$ University of the State of Santa Catarina, Department of Food Engineering and Chemical \\ Engineering, graduate in food engineering \\ ${ }^{2}$ University of the State of Santa Catarina, Department of Food Engineering and Chemical \\ Engineering, doctor in chemistry \\ ${ }^{3}$ University of the State of Santa Catarina, Department of Food Engineering and Chemical \\ Engineering, doctor in food engineering \\ E-mail para contato: raquelbuligon@ hotmail.com
}

\begin{abstract}
Sugarcane is a widely consumed product, giving rise to different products, including sugar, sugarcane juice, and alcohol. The sugarcane juice consists of $81 \%$ water, $15 \%$ sucrose and $1.05 \%$ reducing sugars, being highly perishable, mainly due to its high sugar concentration, high water activity, and low acidity. The present study aimed to evaluate the effect of experimental design (central composite design-CCD) using various pasteurization time-temperature conditions of sugarcane juice packaged in glass bottles, throughout 45 days of storage at $20^{\circ} \mathrm{C}$. A significant $(\mathrm{p} \leq 0.05)$ effect was observed for the interaction time and temperature concerning the variables $\mathrm{pH}$, total reducing sugars, and total soluble sugars, with calculated $\mathrm{F}$ higher than tabulated $\mathrm{F}$, thus allowing constructing a response surface model, which showed that higher temperature and shorter time led to an increase in soluble solids contents. For all treatments, no molds and yeasts, and mesophilic bacteria growth were observed up to 15 days of storage at $20{ }^{\circ} \mathrm{C}$. However, at 30 and 45 days of storage, the growth of molds and yeasts and mesophilic bacteria was observed, with a significant difference between the treatments $(\mathrm{p} \leq 0.05)$ at 45 days of storage, while the pasteurization condition at the central point $\left(80^{\circ} \mathrm{C}\right.$ and 15 minutes) exhibited lower microbial counts.
\end{abstract}

Keywords: Sugarcane juice. Pasteurization. Preservation.

DOI: $10.5965 / 24473650412018012$

\section{INTRODUCTION}

Sugarcane (Sccharum spp) belongs to the grass family Poaceae and remains relevant to the Brazilian economy, with the beginning of its cultivation occurring in the colonial period. Brazil is the world's largest producer of sugarcane, and consequently the largest producer of sugar and ethanol (MAPA, 2018; BORGUESAN et al., 2011).

The crops and the ethanol and sugar producing plants are concentrated mainly in the states of São Paulo, Paraná, and Minas Gerais, besides Mato Grosso do Sul and the northern region with a lesser relevance (MAPA, 2018). Several factors affect the chemical composition of sugarcane, including the climatic conditions during development and maturation, the physical, chemical, and microbiological properties of the soil, and crop type, harvesting season, cut forms 
(manual or mechanical), and crop physiology.

According to Lima et al. (2012), sugarcane consists of $78-86 \%$ water, $10-20 \%$ sucrose, $0.1-2.0 \%$ reducing sugars, $0.3-0.5 \%$ ash, $0.5-1.0 \%$ nitrogen compounds, and $\mathrm{pH}$ ranging from 5.2 to 6.8. Neves et al. (2004) found 18 to $25 \%$ total dissolved solids, representing sugars such as sucrose $(14.5-23.5 \%)$, glucose $(0.2-1.0 \%)$, and fructose $(0-0.5 \%) ; 0.8-1.5 \%$ organic non-sugars (proteins, amides, amino acids, waxes, pectins, coloring materials), and 0.2 - $0.7 \%$ inorganic compounds ( $\mathrm{K}, \mathrm{P}, \mathrm{Ca}, \mathrm{Na}, \mathrm{Mg}, \mathrm{S}, \mathrm{Fe}, \mathrm{Al}$, and $\mathrm{Cl}$ ).

The sugarcane juice is considered a source of carbohydrates, thus it is indicated for the replacement of energy after the practice of physical exercises. It also contains iron, calcium, potassium, sodium, phosphorus, magnesium, and vitamins $\mathrm{C}$ and $\mathrm{B}$ complex. It is also rich in phenolic acid, an antioxidant that helps to prevent heart and nervous system diseases, and cataract (LIMA et al., 2017).

Sugarcane juice is rich in organic and inorganic nutrients, which makes it highly perishable, with high water activity and $\mathrm{pH}$ between 5.0 and 5.5, thus an immediate processing after extraction is recommended (KUNITAKE et al., 2012). The sugarcane juice processing requires higher care, such as preservation technologies for protection against the physical (light, heat), chemical $\left(\mathrm{O}_{2}\right)$, biochemical (enzymes), and biological agents (microorganisms, insects), which are responsible for changes that compromise the chemical (composition), physical (turbidity, phase separation), sensory (odor, flavor, color, texture) and nutritional (protein, vitamin) characteristics of the beverage, influencing its shelf life (LIMA et al., 2017).

The microorganisms found in sugarcane juice are derived from soil and vegetables, including filamentous fungi, yeasts, coliforms, lactic acid bacteria, and sporulated bacteria (KUNITAKE et al., 2012). It may also contain microorganisms from the contamination of mills and other utensils used during the beverage manufacture, as well as handling practices (LIMA et al., 2012).

Molds and yeasts constitute a large group of microorganisms, the majority originating from soil, air, water, and decomposing organic matter. They are capable of developing in products with low water activity and acidity, at $\mathrm{pH}$ between 2.0 and 8.5 . The presence of molds and yeasts in food evidences failures in the manufacturing process, including poor hygienic conditions of equipment, storage, or raw material with excessive contamination (HAMERSKI et al.,2009).

Pasteurization $\left(\mathrm{T}<100{ }^{\circ} \mathrm{C}\right)$ is considered one of the most widespread processing and preservation technologies, and the time/temperature binomial is delineated according to the thermal resistance parameters of the target microorganism or enzyme. Although some microorganisms are destroyed and others injured during the process, the remaining microbial population limits the storage time of food when compared to the commercially sterilized products. Thus, pasteurization is often associated with other preservation methods, such as refrigerated storage, $\mathrm{pH}$ reduction, use of chemical additives, complemented with high-barrier sealed packaging to increase the shelf life of the food product (PRATI et al., 2010).

Therefore, alternatives that allow preserving the microbiological quality of the product, increasing its shelf life, maintaining flavor and the nutritional characteristics need to be developed. In this context, the present study aimed to evaluate various pasteurization conditions of sugarcane juice packaged in hermetically sealed glass bottles, defined by an experimental design, with the physicochemical and microbiological parameters as the responses, during 45 days of storage. 


\section{MATERIAL AND METHODS}

The experiments were conducted at the Food Quality Laboratory (QUALIAL) and Laboratory of Microbiology of the Wesest Higher Education Center- CEO - UDESC (Universidade do Estado de Santa Catarina)- Pinhalzinho/SC.

\subsection{Production of sugarcane packed in a glass bottles}

The juice from sugarcane stalks, cultivar RB 765418 12-month-old, was supplied by a sugar cane brandy industry from the western region of Santa Catarina. The juice was extracted immediately after harvesting, under appropriate sanitary conditions, transported at $7{ }^{\circ} \mathrm{C}$ in plastic bottles, and filtered in a 32 mesh sieve. The $\mathrm{pH}$ was then adjusted to 3.5 with citric acid, and homogenized for subsequent packing into glass bottles of $15 \mathrm{~cm}$ height, $3 \mathrm{~cm}$ aperture, 5.5 $\mathrm{cm}$ width, and $250 \mathrm{~mL}$ volume, with hermetic cap, suitable for juice packaging (MACHADO et al.,2013).

Then, the pasteurization was carried out in a water bath, controlling the temperature with the aid of a thermometer. Different time and temperature conditions were used, according to a $2^{2}$ central composite design (CCD) as follows: condition $1\left(70{ }^{\circ} \mathrm{C} / 10\right.$ minutes), condition 2 $\left(70{ }^{\circ} \mathrm{C} / 20\right.$ minutes), condition $3\left(90{ }^{\circ} \mathrm{C} / 10\right.$ minutes $)$, condition $4\left(90{ }^{\circ} \mathrm{C} / 20\right.$ minutes $)$, and condition 5 (central point, $80{ }^{\circ} \mathrm{C} / 15$ minutes), as reported by Kunitake et al. (2012). The analyses were performed ( $\mathrm{pH}$, total soluble solids, titratable acidity, turbidity and total reducing sugars) at 15, 30, and 45 days of storage at $20^{\circ} \mathrm{C}$, as described by Prati et al. (2004).

\subsection{Microbiological characterization}

Molds and yeasts counts were performed by inoculating $0.1 \mathrm{~mL}$ sample on a dry surface of plates with Potato Agar Glucose, which was incubated without inverting at $25^{\circ} \mathrm{C}$ for 5 to 7 days. For aerobic mesophilic bacteria counts, $0.1 \mathrm{~mL}$ aliquots were scattered on the surface of Petri dishes and incubated at $35-37{ }^{\circ} \mathrm{C}$ for 48 hours (MAPA, 2003).

\subsection{Physicochemical characterization}

The samples were characterized for $\mathrm{pH}$, total soluble solids, titratable acidity expressed as citric acid, turbidity (MSTECNOPON TB 1000P) in NTU (Turbidity Nephelometric Unit), total reducing sugars by the Lane-Eynon methodology, and ascorbic acid by the Tillmans's method. The analyses were performed according to the methodology of the Association of Official Analytical Chemists - AOAC (2012).

\subsection{Statistical analysis}

Data were analyzed using the software Protimiza, with a level of significance of $p \leq 0.05$ $\%$, and the differences were analyzed by the Tukey's test. All analyses were carried out in triplicate, obtaining the average of the results, which were also presented graphically by the Origin software ${ }^{\circledR}$. 


\section{RESULTS AND DISCUSSION}

\subsection{Physicochemical characterization of pasteurized sugarcane juice}

The sugarcane juice in natura was subjected to different heat treatment conditions $\left(2^{2}\right.$ CCD), to verify the effect of the treatments on the physicochemical characteristics of the product during 45 days of storage. Figure 1 shows the results for (a) turbidity, (b) total soluble solids, (c) ascorbic acid, (d) total acidity, (e) $\mathrm{pH}$, and (f) total reducing sugars. 
Figure 1- Determination of (a) turbidity, (b) total soluble solids, (c) ascorbic acid, (d) total acidity, (e) $\mathrm{pH}$, and (f) total reducing sugars of sugarcane juice subjected to different time and temperature conditions, according to experimental design, as follows: $\boldsymbol{\nabla}\left(70{ }^{\circ} \mathrm{C} / 10 \mathrm{~min}\right)$,

(70 $\left.{ }^{\circ} \mathrm{C} / 20 \mathrm{~min}\right),\left(90^{\circ} \mathrm{C} / 10 \mathrm{~min}\right), \mathrm{X}\left(90^{\circ} \mathrm{C} / 20 \mathrm{~min}\right), \boldsymbol{\Delta}\left(80^{\circ} \mathrm{C} / 15 \mathrm{~min}\right)$ during 45 days of storage

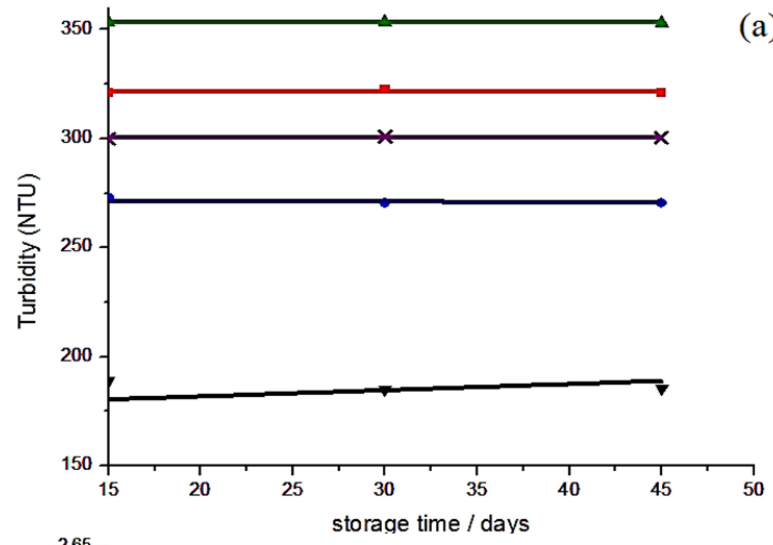

(a)
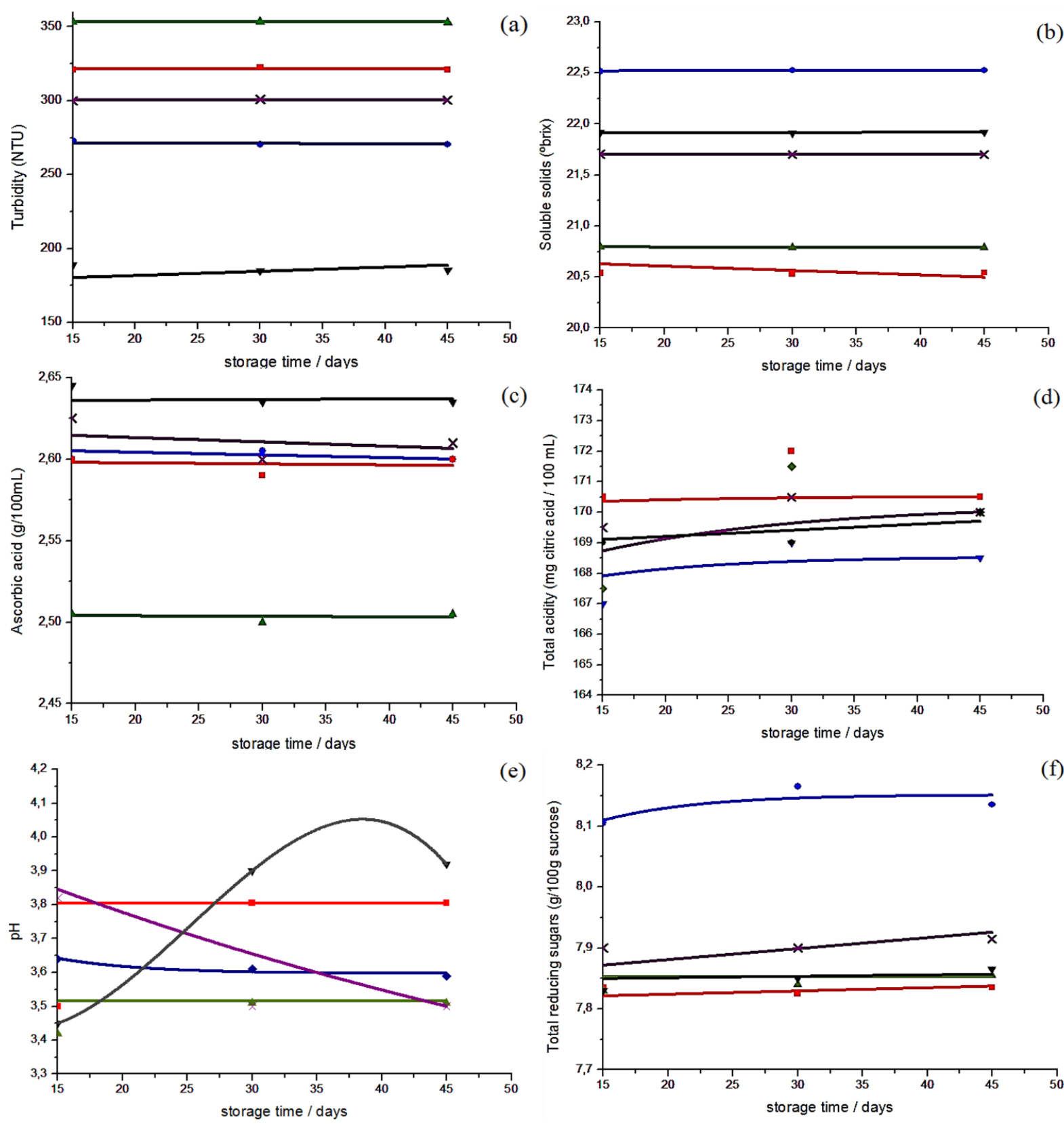

(e)

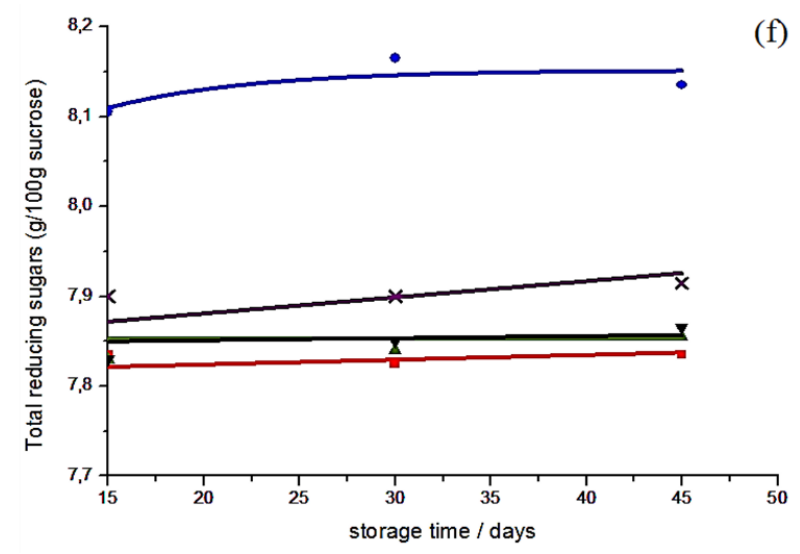

Source: authored by the author (2018).

As shown in Figure 1 (a), the turbidity values of sugarcane juice ranged from 189 to 353 NTU, and the lowest value was obtained at $70{ }^{\circ} \mathrm{C}$ for 10 minutes. These differences may be due to the presence of precipitates from the heat treatment (OLIVEIRA et al., 2007). Another relevant factor reported by Silva and Faria (2006) about the increase in turbidity of sugarcane juice may be the presence of compounds such as gums, starch, and protein.

A tendency to increase the turbidity was observed in the treatments at 20 and 15 minutes, 
Aceito em:

$21 / 11 / 2018$

while the storage time did not affect this parameter. Oliveira et al. (2007) evaluated sugarcane juice with the addition of $4 \%$ lemon juice (v/v), pasteurized at $70{ }^{\circ} \mathrm{C}$ for 25 minutes, and found turbidity of $180.21 \mathrm{NTU}$, close to that found in the present study in the condition of $70{ }^{\circ} \mathrm{C}$ for 10 minutes.

The soluble solids content of sugarcane juice is shown in Figure 1 (b) varied between 20.54 and $22.52{ }^{\circ}$ Brix, and higher temperatures and shorter times resulted in an increased on solids contents. Similar behavior was reported by Kunitake et al. (2012) in sugarcane juice with the addition of passion fruit pulp, with solids contents ranging from 22.2 to $24.13 \%$, and the highest value obtained at $90{ }^{\circ} \mathrm{C}$ for 30 seconds. It is noteworthy that the soluble solids concentration can undergo changes in the presence of molds and yeasts, once they consume the available sugars by fermentation (LIMA et al., 2017).

Small changes were observed in the ascorbic acid content (c) among the treatments, ranging from 2.48 to $2.63 \mathrm{mg} / 100 \mathrm{~mL}$ over 45 days of storage, similar to the value reported by Oliveira et al. (2007), of $3.04 \mathrm{mg} / 100 \mathrm{~mL}$ ascorbic acid in sugarcane subjected to pasteurization at $70{ }^{\circ} \mathrm{C}$ for 25 minutes. These differences can be due to the use of different time, temperature, raw material, and processing conditions. Kunitake et al. (2012) emphasized that oxidation is the main degradation mechanism of ascorbic acid, thus a reduction in its content during storage is expected, which was observed in the present study.

The acidity (d) of the pasteurized sugarcane juice ranged from 167.00 to $172.00 \mathrm{mg}$ citric acid/100 mL. A linearity in the concentration of citric acid for the sample subjected to $80{ }^{\circ} \mathrm{C} / 15$ min was observed, whereas variations were observed in the other samples during the 45 days of storage, with greater evidence for the treatment of $90{ }^{\circ} \mathrm{C} / 10 \mathrm{~min}$. In addition, it was also observed that a higher pasteurization time resulted in higher acidity of the product along the days of storage probably due to the microbial growth, as also reported by Oliveira et al.(2007).

Silva and Faria (2006) studied sugarcane juice submitted to $140{ }^{\circ} \mathrm{C}$ for $10 \mathrm{~s}$ and stored in sterile glass bottles for 45 days of storage. The acidity remained at $170 \mathrm{mg}$ citric acid/100 mL, which is close to that found in this study for all conditions. The different results demonstrate the difficulty of correlating the effect of the pasteurization temperature, which also depends on the composition of the raw material.

The $\mathrm{pH}$ values of sugarcane juice subjected to the different treatments are shown in Figure 1 (e). For the condition $4\left(90{ }^{\circ} \mathrm{C}\right.$ and 20 minutes), there was a decrease in $\mathrm{pH}$ up to 30 days of storage, unlike the condition $1\left(70{ }^{\circ} \mathrm{C}\right.$ and 10 minutes) that exhibited an increase in $\mathrm{pH}$, with a difference of $66 \%$ between the higher and the lower $\mathrm{pH}$ value. The $\mathrm{pH}$ values found in the present study corroborate the findings of Machado et al. (2013), who studied sugarcane juice with the addition of $0.13 \%\left(\mathrm{w} / \mathrm{w}\right.$ ) of citric acid, submitted to $90^{\circ} \mathrm{C}$ for 10 minutes with $\mathrm{pH}$ of 4.5 after the treatment.

Oliveira et al. (2007) investigated the sugarcane juice containing $4 \%$ lemon juice and found a higher $\mathrm{pH}$ value (3.66) when compared to the $\mathrm{pH}$ of the control (3.62). This result may be due to evaporation or oxidation of citric acid during the heat treatment, in addition to microbiological reactions caused by the development of bacteria and molds, or even chemical and biochemical reactions in the processed product.

The total reducing sugar contents (f) of sugarcane juice remained intact over the 45 days of storage for all the conditions studied, and ranged from 7.83 to $8.11 \mathrm{~g} / 100 \mathrm{~g}$ of sucrose, with a higher content at the condition of $90{ }^{\circ} \mathrm{C}$ for 10 minutes, which shows that more intense temperature leads to an increase in reducing sugars.

Machado et al. (2013) subjected sugarcane juice to heat treatment at $90{ }^{\circ} \mathrm{C} / 10$ minutes, and found total sugars of $7.60 \mathrm{~g} / 100 \mathrm{~g}$ sucrose, while OLIVEIRA et al. (2007) found a value 
lower than $17.28 \mathrm{~g} / 100 \mathrm{~g}$ sucrose in sugarcane juice containing $10 \%(\mathrm{v} / \mathrm{v})$ pineapple juice subjected to pasteurization at $70{ }^{\circ} \mathrm{C}$ for 25 minutes. The authors emphasized that the addition of pineapple juice to the product increased the total reducing sugars content.

Statistical analysis: Table 1 presents the physicochemical characteristics of both the sugarcane juice in natura $(\mathrm{S} / \mathrm{T})$ and that subjected to different pasteurization conditions established in the experimental design for 15 days of storage at $20{ }^{\circ} \mathrm{C}$, with no microbial growth during this period.

Table 1- Experimental design $\left(2^{2} \mathrm{CCD}\right)$ with the coded and actual values, for the treated and untreated sample (S/T), with the responses for turbidity, $\mathrm{pH}$, soluble solids (SS), ascorbic acid (AA), total acidity, and total reducing sugars (TRS) of the sugarcane juice after pasteurization and 15 days of storage

\begin{tabular}{|c|c|c|c|c|c|c|c|c|}
\hline \multicolumn{4}{|c|}{ Indenpendent variables } & \multicolumn{5}{|c|}{ Dependent variables } \\
\hline Treatment & $\begin{array}{l}\text { Time } \\
(\text { min) }\end{array}$ & $\begin{array}{c}\text { Temperature } \\
\left({ }^{\circ} \mathbf{C}\right)\end{array}$ & $\begin{array}{l}\text { Turbidity } \\
\text { (NTU) }\end{array}$ & $\begin{array}{c}\text { SS } \\
\left({ }^{\circ} \text { brix }\right)\end{array}$ & $\underset{(\mathbf{m g} / \mathbf{1 0 0 m L})}{\mathbf{A A}}$ & $\begin{array}{r}\text { Total Acidity } \\
(\mathrm{mg} / \mathbf{1 0 0 m L})\end{array}$ & $\mathbf{p H}$ & $\begin{array}{c}\text { TRS } \\
(\mathrm{g} / \mathbf{1 0 0 g})\end{array}$ \\
\hline 1 & $-1(10)$ & $-1(70)$ & $273 \pm 0.01^{\mathrm{a}}$ & $22.52 \pm 0.01^{\mathrm{a}}$ & $2.60 \pm 0.01^{\mathrm{a}}$ & $167.00 \pm 0.01^{\mathrm{a}}$ & $3.64 \pm 0.01^{\mathrm{a}}$ & $8.11 \pm 0.01^{\mathrm{a}}$ \\
\hline 2 & $1(20)$ & $-1(70)$ & $323 \pm 0.01^{\mathrm{b}}$ & $20.54 \pm 0.01^{b}$ & $2.60 \pm 0.01^{\mathrm{b}}$ & $170.50 \pm 0.71^{\mathrm{a}}$ & $3.50 \pm 0.01^{b}$ & $7.84 \pm 0.01^{b}$ \\
\hline 3 & $-1(10)$ & $1(90)$ & $353 \pm 0.71^{\mathrm{c}}$ & $20.80 \pm 0.01^{\mathrm{c}}$ & $2.51 \pm 0.04^{\mathrm{a}}$ & $167.50 \pm 0.71^{\mathrm{a}}$ & $3.42 \pm 0.01^{\mathrm{c}}$ & $7.83 \pm 0.01^{\mathrm{c}}$ \\
\hline 4 & $1(20)$ & $1(90)$ & $300 \pm 0.01^{\mathrm{d}}$ & $21.71 \pm 0.01^{\mathrm{d}}$ & $2.63 \pm 0.02^{\mathrm{a}}$ & $169.50 \pm 0.71^{\mathrm{a}}$ & $3.82 \pm 0.01^{\mathrm{d}}$ & $7.90 \pm 0.01^{\mathrm{d}}$ \\
\hline 5 & $0(15)$ & $0(80)$ & $189 \pm 0.01^{\mathrm{e}}$ & $21.92 \pm 0.02^{\mathrm{e}}$ & $2.65 \pm 0.01^{b}$ & $172.50 \pm 0.01^{\mathrm{a}}$ & $3.45 \pm 0.01^{\mathrm{e}}$ & $7.83 \pm 0.01^{\mathrm{e}}$ \\
\hline 6 & $0(15)$ & $0(80)$ & $223 \pm 0.71 \mathrm{e}$ & $21.90 \pm 0.01^{\mathrm{e}}$ & $2.55 \pm 0.02^{\mathrm{b}}$ & $172.00 \pm 0.01^{\mathrm{a}}$ & $3.47 \pm 0.01^{\mathrm{e}}$ & $7.85 \pm 0.01^{\mathrm{e}}$ \\
\hline 7 & $0(15)$ & $0(80)$ & $225 \pm 2.12^{\mathrm{e}}$ & $21.92 \pm 0.01^{\mathrm{e}}$ & $2.48 \pm 0.02^{\mathrm{b}}$ & $170.00 \pm 0.01^{\mathrm{a}}$ & $3.46 \pm 0.01^{\mathrm{e}}$ & $7.88 \pm 0.01^{\mathrm{e}}$ \\
\hline $\mathbf{S} / \mathbf{T}$ & - & - & $163 \pm 0.01$ & $22.53 \pm 0.01$ & $2.81 \pm 0.03$ & $98.00 \pm 0.01$ & $5.23 \pm 0.01$ & $8.11 \pm 0.01$ \\
\hline
\end{tabular}

Means followed by different lowercase letters in the columns differ statistically from each other $(\mathrm{p} \leq 0.05)$ by Tukey's test, for various pasteurization conditions and storage time of 15 days.

Source: authored by the author (2018).

The sugarcane juice in natura (S/T) (Table1) exhibited pH 5.23 and soluble solids of $22.53^{\circ}$ Brix, which is similar to the findings of Kunitake et al., (2014), with values of 5.16 and $21.10^{\circ} \mathrm{Brix}$ for $\mathrm{pH}$ and soluble solids, respectively.

Oliveira et al. (2007) evaluated sugarcane juice in natura and found total reducing sugars and ascorbic acid contents of $17.68 \mathrm{~g} / 100 \mathrm{~g}$ sucrose and $2.98 \mathrm{mg} / 100 \mathrm{~mL}$ respectively, which is close to the present study, with values of $8.11 \mathrm{~g} / 100 \mathrm{~g}$ sucrose and $2.81 \mathrm{mg} / 100 \mathrm{~mL}$, respectively. The turbidity and acidity values of the samples of the present study were 163 NTU and $98.00 \mathrm{mg}$ citric acid/100 mL, respectively, while Prati (2010) and Sanda (2016) found 87.80 
NTU and $41.00 \mathrm{mg}$ citric acid/100 mL, respectively, in sugarcane juice in natura.

According to Qudsieh et al. (2002), browning is one of the most important changes occurring shortly after the sugarcane juice extraction, which is related to the formation of melanoidins from the Maillard reaction between the reducing sugars and amino acids present in the sugarcane.

The turbidity values were up to $353 \mathrm{NTU}$ for the condition $3\left(90{ }^{\circ} \mathrm{C} / 10 \mathrm{~min}\right)$ with significant differences $(\mathrm{p} \leq 0.05)$ among the treatments, as well as the soluble solids content ranging from 20.54 to $22.52{ }^{\circ}$ Brix, for both the conditions $1\left(70{ }^{\circ} \mathrm{C} / 10 \mathrm{~min}\right)$ and $2\left(70{ }^{\circ} \mathrm{C} / 20\right.$ $\min )$.

The ascorbic acid contents ranged from 2.48 to $2.65 \mathrm{mg} / 100 \mathrm{~mL}$, for both the conditions 7 (central point, $80{ }^{\circ} \mathrm{C} / 15 \mathrm{~min}$ ) and $4\left(90{ }^{\circ} \mathrm{C} / 10 \mathrm{~min}\right.$ ). According to the Tukey's test, no significant differences were observed among the conditions $1\left(70{ }^{\circ} \mathrm{C} / 10 \mathrm{~min}\right), 3\left(90^{\circ} \mathrm{C} / 10 \mathrm{~min}\right)$, and $4\left(90^{\circ} \mathrm{C} / 20 \mathrm{~min}\right)$, which were statistically different from the conditions $2\left(70{ }^{\circ} \mathrm{C} / 20 \mathrm{~min}\right)$, 5,6 , and $7\left(80^{\circ} \mathrm{C} / 15 \mathrm{~min}\right)$ at $\mathrm{p} \leq 0.05$.

The acidity of the pasteurized sugarcane juice ranged from 167.00 to $172.50 \mathrm{mg}$ citric $\mathrm{acid} / 100 \mathrm{~mL}$, for both the conditions $3\left(90^{\circ} \mathrm{C} / 10 \mathrm{~min}\right.$ ) and 5 (central point, $80{ }^{\circ} \mathrm{C} / 15 \mathrm{~min}$ ), with no significant difference $(\mathrm{p} \leq 0.05)$ among the treatments. However, $\mathrm{pH}$ presented a significant difference $(\mathrm{p} \leq 0.05)$ between the treatments.

The total reducing sugars contents, expressed as $\mathrm{g} / 100 \mathrm{~g}$ sucrose, ranged from 7.83 to 8.11, for the conditions 5 (central point, $\left.80^{\circ} \mathrm{C} / 15 \mathrm{~min}\right), 3\left(90^{\circ} \mathrm{C} / 10 \mathrm{~min}\right)$, and $1\left(70{ }^{\circ} \mathrm{C} / 10 \mathrm{~min}\right.$ ), with significant differences $(\mathrm{p} \leq 0.05)$ among them.

Statistical analysis of data of the samples at 15 days of storage at $20{ }^{\circ} \mathrm{C}$ indicated that the pasteurization time and temperature had no influence on turbidity, ascorbic acid, and total acidity values. For $\mathrm{pH}$, a significant effect $(\mathrm{p} \leq 0.05)$ was observed for the interaction time and temperature, with calculated $\mathrm{F}$ of 7.20 , higher than the tabulated $\mathrm{F}$ of 6.61 , with an $\mathrm{R}^{2}$ of $58.91 \%$, making it impossible to construct the response surface and the mathematical model.

For the total reducing sugars, there was a significant effect $(\mathrm{p} \leq 0.05)$ for the interaction time and temperature, with a calculated $\mathrm{F}$ lower than the tabulated F, making it impossible to construct a mathematical model and a response surface for this parameter.

With respect to the total soluble solids, a significant effect $(p \leq 0.05)$ was observed for the interaction time and temperature, with the calculated $\mathrm{F}(12.6)$ higher than the tabulated $\mathrm{F}(6.61)$ and $\mathrm{R}^{2}$ of 71.63, making possible the construction of the mathematical model and the response surface. The Equation 1 presents the coded second-order model, which describes the soluble solids content as a function of time (x1) and pasteurization temperature (x2) within the range studied. The validation of the model allows the construction of the response surface in Figure 2 , which shows that the higher soluble solids were observed in lower time (10 minutes) and higher temperature $\left(90^{\circ} \mathrm{C}\right)$ conditions.

Soluble Solids $\left({ }^{\circ} \mathrm{Brix}\right)=21.62+0.72 \mathrm{x}_{1} \mathrm{x}_{2}$

(Eq. 1) 
Figure 2 - Response surface of the soluble solids content of the pasteurized sugarcane juice stored for 15 days, according to the $2^{2} \mathrm{CCD}$ experimental design.

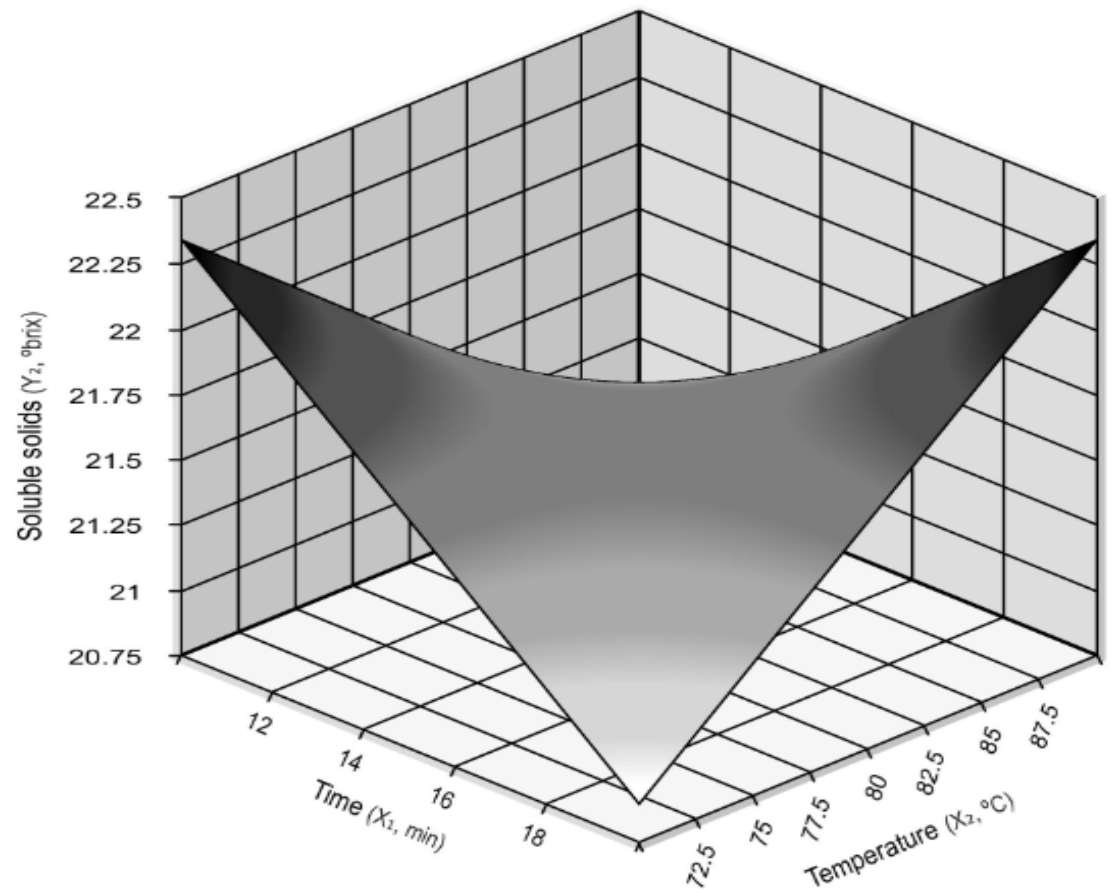

Source: authored by the author (2018).

\subsection{Microbiological characterization of sugarcane juice packaged in glass bottles}

Table 2 presents the results of the microbiological parameters of both the sugarcane juice in natura (S/T) and the juice subjected to different pasteurization conditions, at 15, 30, and 45 days of storage at $20{ }^{\circ} \mathrm{C}$. The sugarcane juice in natura presented molds and yeasts counts of $200 \times 10^{1} \mathrm{CFU} / \mathrm{mL}$ and mesophilic bacteria counts of $120 \times 10^{1} \mathrm{CFU} / \mathrm{mL}$.

After 15 days of storage, there was no microbial growth for all treatments, while both molds and yeasts and mesophilic bacteria counts increased after 30 and 45 days of storage, as shown in Table 2. For molds and yeasts counts, a decimal reduction $(1.00 \mathrm{log})$ was observed in the sugarcane juice in natura when compared to the sample subjected to pasteurization in the condition of the central point $\left(80^{\circ} \mathrm{C}\right.$ and 15 minutes).

Rezzadori et al. (2013) investigated sugarcane juice containing 5\% passion fruit pulp, subjected to microfiltration and pasteurization at $90^{\circ} \mathrm{C} / 30 \mathrm{~s}$ and $95^{\circ} \mathrm{C} / 30 \mathrm{~s}$, and found molds and yeasts counts $<10 \mathrm{CFU} / \mathrm{mL}$.

Oliveira et al. (2007) found yeasts and molds counts of $1.4 \times 10^{6} \mathrm{CFU} / \mathrm{mL}$ in sugarcane in natura, and Kunitake et al., 2014 found $3.8 \times 10^{3} \mathrm{CFU} / \mathrm{mL}$ for mesophilic bacteria. The present study found molds and yeasts and mesophilic bacteria counts of $200 \times 10^{1} \mathrm{CFU} / \mathrm{mL}$ and $120 \times 10^{1} \mathrm{CFU} / \mathrm{mL}$, respectively. However, it is worth emphasizing that these differences can be due to several factors such as species of raw material, climate, relief, soil, cultivation technique, among others (HUANG et al., 2015). 
Aceito em:

$21 / 11 / 2018$

Table 2 - Experimental design $\left(2^{2}\right)$ with the coded and actual values, with the responses for molds and yeasts counts, and mesophilic bacteria counts of the pasteurized sugarcane juice at 30 and 45 days of storage.

\begin{tabular}{|c|c|c|c|c|c|c|}
\hline \multirow{2}{*}{\multicolumn{3}{|c|}{ Independent Variables }} & \multicolumn{4}{|c|}{ Dependent Variables } \\
\hline & & & \multicolumn{2}{|c|}{ Molds and Yeasts CFU.ml ${ }^{-1}$} & \multicolumn{2}{|c|}{ Mesophilic bacteria } \\
\hline Treatment & $\begin{array}{l}\text { Time } \\
(\min )\end{array}$ & $\begin{array}{c}\text { Temperature } \\
\left({ }^{\circ} \mathrm{C}\right)\end{array}$ & 30 days & 45 days & 30 days & 45 days \\
\hline 1 & $-1(10)$ & $-1(70)$ & $107.00 \pm 1.41^{\mathrm{a}, \mathrm{A}}$ & $150.00 \pm 2.80^{\mathrm{a}, \mathrm{B}}$ & $112.00 \pm 2.85^{\mathrm{a}, \mathrm{A}}$ & $32.00 \pm 1.03^{\mathrm{a}, \mathrm{B}}$ \\
\hline 2 & $1(20)$ & $-1(70)$ & $94.00 \pm 1.12^{\mathrm{b}, \mathrm{A}}$ & $97.00 \pm 1.80^{\mathrm{b}, \mathrm{B}}$ & $115.00 \pm 2.63^{\mathrm{a}}{ }^{\mathrm{A}}$ & $35.00 \pm 1.12^{\mathrm{b}, \mathrm{B}}$ \\
\hline 3 & $-1(10)$ & $1(90)$ & $77.00 \pm 3.54^{\mathrm{c}, \mathrm{A}}$ & $133.00 \pm 2.83^{\mathrm{C}, \mathrm{B}}$ & $18.00 \pm 2.99^{\mathrm{bA}}$ & $37.00 \pm 1.37^{\mathrm{c}, \mathrm{B}}$ \\
\hline 4 & $1(20)$ & $1(90)$ & $67.00 \pm 1.01^{\mathrm{d}, \mathrm{A}}$ & $87.00 \pm 3.12^{\mathrm{d}, \mathrm{B}}$ & $17.00 \pm 6.30^{\mathrm{b}, \mathrm{A}}$ & $23.00 \pm 1.43^{\mathrm{d}, \mathrm{B}}$ \\
\hline Central & $0(15)$ & $0(80)$ & $17.00 \pm 2.95^{\mathrm{e}, \mathrm{A}}$ & $47.50 \pm 2.90^{\mathrm{e}, \mathrm{B}}$ & $10.00 \pm 7.10^{\mathrm{b}, \mathrm{A}}$ & $19.00 \pm 1.09^{\mathrm{e}, \mathrm{B}}$ \\
\hline
\end{tabular}

Mean followed by different lowercase letters in the columns and different uppercase letters in the rows, for molds and yeasts and mesophilic bacteria counts at different storage periods and pasteurization temperatures differ statistically from each other $(\mathrm{p} \leq 0.05)$ by Tukey's test. Source: authored by the author (2018).

Significant differences $(\mathrm{p} \leq 0.05)$ were observed among the treatments by the Tukey's test for molds and yeasts counts at 30 and 45 days of storage. The condition $1\left(70{ }^{\circ} \mathrm{C}\right.$ and 10 minutes) had the highest counts, while the condition at the central point $\left(80^{\circ} \mathrm{C}\right.$ and 15 minutes) resulted in lower molds and yeasts counts.

For the mesophilic bacteria, a significant difference $(\mathrm{p} \leq 0.05)$ was observed for all treatments only at 45 days of storage. After 30 days, the conditions $1\left(70{ }^{\circ} \mathrm{C} / 10 \mathrm{~min}\right)$ and $2(70$ ${ }^{\circ} \mathrm{C} / 20 \mathrm{~min}$ ) had the highest mesophilic bacteria counts, with no significant difference between them. The lower counts were observed in the other conditions, thus the higher temperatures lead to a lower mesophilic bacteria counts.

As can be seen in Table 2, a significant difference $(p \leq 0.05)$ was observed in molds and yeasts and mesophilic bacteria counts between the storage periods ( 30 and 45 days) at $20{ }^{\circ} \mathrm{C}$ for all treatments, indicating a product inadequate for consumption. HUANG et al. (2015) studied sugarcane juice submitted to high pressure and thermal pasteurization, and found counts of 7.98 and $4.96 \mathrm{CFU} / \mathrm{mL}$ for coliforms and mesophilic bacteria, respectively, after 28 days of storage. Karmakar et al. (2011) submitted sugarcane to pasteurization at temperatures of 80, 85, 90 , and $95^{\circ} \mathrm{C}$ for 2 minutes, and found total microbial counts between 150 and $250 \mathrm{CFU} / \mathrm{mL}$ after storage at $25^{\circ} \mathrm{C}$ for 25 days. Thus, the lower the pasteurization temperature, the higher the microbial counts throughout the storage, which was also observed in the present study at 45 days of storage for the conditions 1 and 2 .

\section{CONCLUSION}

The pasteurization of sugarcane juice in the condition of $80^{\circ} \mathrm{C}$ for 15 minutes, considered not very low or very aggressive treatment, maintained the physicochemical characteristics of 
the product, contributing with the elimination and inactivation of pathogenic microorganisms, and preserving the product at room temperature for a few days. Studies are required to ensure the efficiency of the process, including the evaluation of the product under refrigerated storage, as well as the sensory evaluation as an alternative to prove the effectiveness of the treatment.

\section{REFERENCES}

AOAC. Official methods of analysis. 15 ed. Arlington: Association of official analytical chemists, 1990.

DELGADO, C. Elementos da tecnologia e engenharia de açúcar de cana. Departamento de Tecnologia Rural - ESAL, Piracicaba, SP, v. 1. 1977.

HAMERSKI, F. Estudo de variáveis no processo de carbonatação do caldo de cana-deaçúcar. 2009. Tese (Doutorado em Engenharia de Alimentos) - Universidade Federal do Paraná (UFPR), Programa de Pós-graduação em Ciência e Tecnologia de alimentos, Curitiba, 2009.

HUANG, H. W.; CHANG, Y. H.; WANG, C. Y. High Pressure pasteurization of sugarcane juice: evaluation of microbiological shelf life and quality evolution during refrigerated storage. Food and Bioprocess Technology, [s.l.], v. 8, p. 2483-2494, 2015.

INSTITUTO ADOLFO LUTZ (IAL). Normas analíticas do Instituto Adolfo Lutz: métodos químicos e físicos para análise de alimentos. 3 ed. São Paulo: IAL, 1985.

KARMAKAR, R.; GHOSH, A, K. Effect of pre treatment son physico- chemical characteristics of sugar cane juice. Sugar Tech, [s.l.], v. 13, p. 47-50, 2011.

KUNITAKE, M. T. Processamento e estabilidade de caldo de cana acidificado. 2012. 131 f. Dissertação (Mestrado em Ciências) - Faculdade de Zootecnia e Engenharia de Alimentos, Universidade de São Paulo, Pirassununga, 2012.

Lima, R, B. Processo de clarificação de caldo de cana-de-açúcar aplicando elétrons acelerados. 2012. 125 f. Tese (Doutorado em Ciências) - Instituto de Pesquisas Energéticas e Nucleares - Autarquia Associada à Universidade de São Paulo, 2012.

Lima, D, T, et al. Organic carbono and carbon stock: relations with physical indicator sand soil aggregation in areascultivatedwith sugar cane. Tropical and Subtropical Agroecosystems, [s.l.], v.1, p. 20, 2017.

MACHADO, D. Esterilização e engarrafamento de caldo de cana: avaliação sensorial e fisicoquímica. Centro Ciêntifíco Conhecer, [s.l.], v.9, p.2271, 2013.

MAPA-MINISTÉRIO DA AGRICULTURA, PECUÁRIA E ABASTECIMENTO. Secretaria de Defesa Agropecuária. 2018.

NEVES, E. O. Composição de minerais em caldo de cana-de-açúcar e em vinho tinto artesanal de mesa. 2004. 70 f. Dissertação (Mestrado em Ciência e Tecnologia de Alimentos) 
- Universidade Federal de Viçosa, Viçosa, MG, 2004.

OLIVEIRA, A. C. G. et al. Efeitos do processamento térmico e da radiação gama na conservação de caldo de cana puro e adicionado de suco de frutas. Ciência e Tecnologia de Alimentos, Campinas, v. 27, n. 4, p. 863-873, out./dez. 2007.

OLIVEIRA, T. B. A. et al. Tecnologia e custos de produção de cana-de-açúcar: um estudo de caso em uma propriedade agrícola. Latin American Journal of Business Management, Taubaté, SP, v. 3, n. 1, p. 150-172, jan./jun. 2012.

PRATI, P. Estudo da vida-de-prateleira de bebidas elaborada pela mistura de garapa parcialmente clarificada- estabilizada e suco natural de maracujá. Boletim do Centro de Pesquisa de Processamento de Alimentos, [s.l.], v. 2, n. 22, p. 295-310, 2010.

QUDSIEH, H, Y, et al. Effect of maturity on chlorophyll, tannin, color and polyphenol oxidase (PPO) activity of sugarcane (Saccharum officinarum var. yellow cane). Journal of Agriculture and Food Chemistry, v. 50, n. 6, p. 1615- 1618, 2002.

REZZADORI, K. et al. Effects of tangential microfiltration and pasteurization on the rheological, microbiological, physico-chemical and sensory characteristics of sugar cane juice. International Journal of Food Science \& Technology, [s.l.], v. 48, p. 1-9, 2013.

SANDA, A, C, M, M; SILVA, A. R, A, Silva, T, L. Desenvolvimento de caldo de cana pasteurizado adicionado de frutas ácidas. Revista Brasileira de Tecnologia Agroindustrial, [s.l.], v. 10, p.1, 2016.

SILVA, K. S. da; FARIA, J. de A. F. Avaliação da qualidade de caldo de cana envasado a quente e por sistema asséptico. Ciência e Tecnologia de Alimentos, [s.l.], v. 26, n. 4, p. 754758, out./dez. 2006. 